\title{
Attendance rate in icu follow up clinics: an analysis of patients that attend the ICU clinic compared to those that do not attend
}

\author{
M Colomo*, E Smithers, J Cherian, A Pareed, G De la Cerda \\ From ESICM LIVES 2015 \\ Berlin, Germany. 3-7 October 2015
}

\section{Introduction}

In the UK, the implementation of ICU follow up services is becoming a standard of care after the National Institute of Health and Care Excellence (NICE) in 2009 published clinical guideline 83 (CG83) on rehabilitation after critical illness [1].

\section{Objectives}

To compare the characteristics of the patients that attend our ICU follow up clinic with those that do not attend (DNA) with the objective of improving the selection of patients and decreasing the DNA rate.

\section{Methods}

Retrospective cohort analysis of prospective collected data at a tertiary centre from November 2011 to March 2015. The clinic is run monthly by an ICU consultant and a critical care outreach nurse. Criteria to be invited to the clinic are mechanical ventilation $\geq 3$ days. Demographics, duration of mechanical ventilation, ICU and hospital length of stay, attendance/DNA to the follow up services and reason for not attendance were collected.

\section{Results}

A total of 116 patients met the criteria to be invited to the clinic. DNA rate was $44 \%$ which is similar to other series reported in the literature. Patients who DNA required a longer length of mechanical ventilation (10.05 days vs $12.42 ; \mathrm{p}=0.24)$, and a longer LOS in ICU (16.11 VS 19.96; $\mathrm{p}=0.13$ ) and in hospital (30.7 vs $34.5 ; \mathrm{p}=0.31)$ although these differences are not statistically significant. Regarding the known reasons for not attending clinic, (in $39 \%$ of the cases the reason was

Queen's Hospital, London, United Kingdom unknown) the most frequent one was that the patient was very well and did not feel beneficial to attend (12 patients). On the contrary, the rest of the patients who failed to attend were either too unwell \& disabled (6), still in hospital \& readmitted (9), had no transport means (5), or had died (4).

\section{Conclusions}

1. The DNA rate in our clinic is still high.

2. Patients that do not attend are either too well or too sick to attend.

3. It is necessary to improve our selection criteria to this clinic to decrease the DNA rate and optimize the service.

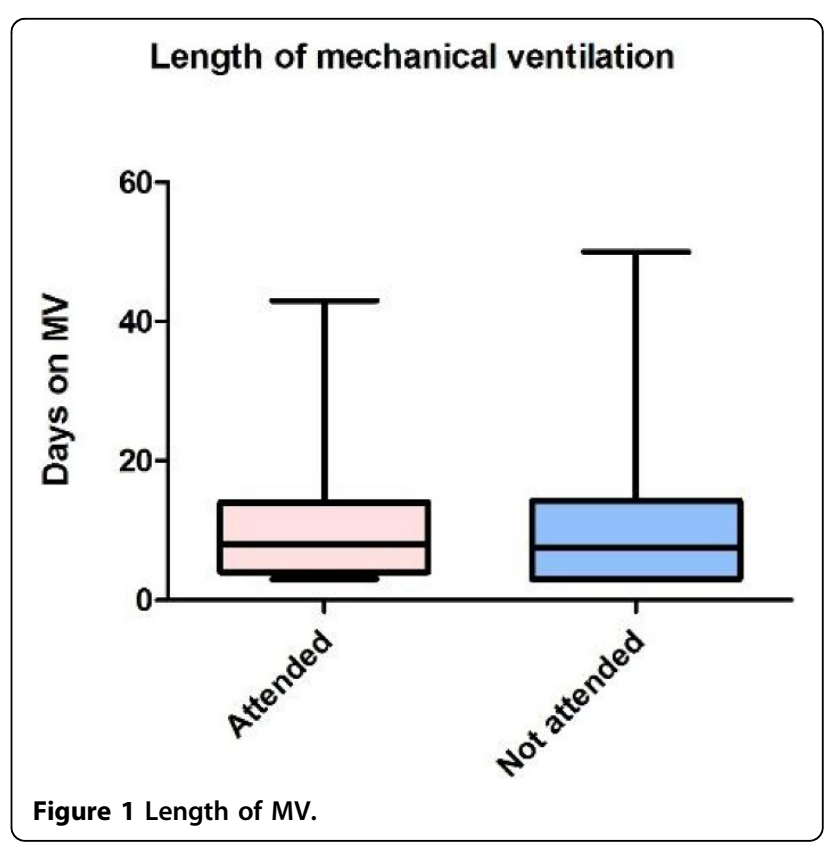

C 2015 Colomo et al.; This is an Open Access article distributed under the terms of the Creative Commons Attribution License (http:// creativecommons.org/licenses/by/4.0), which permits unrestricted use, distribution, and reproduction in any medium, provided the original work is properly cited. 

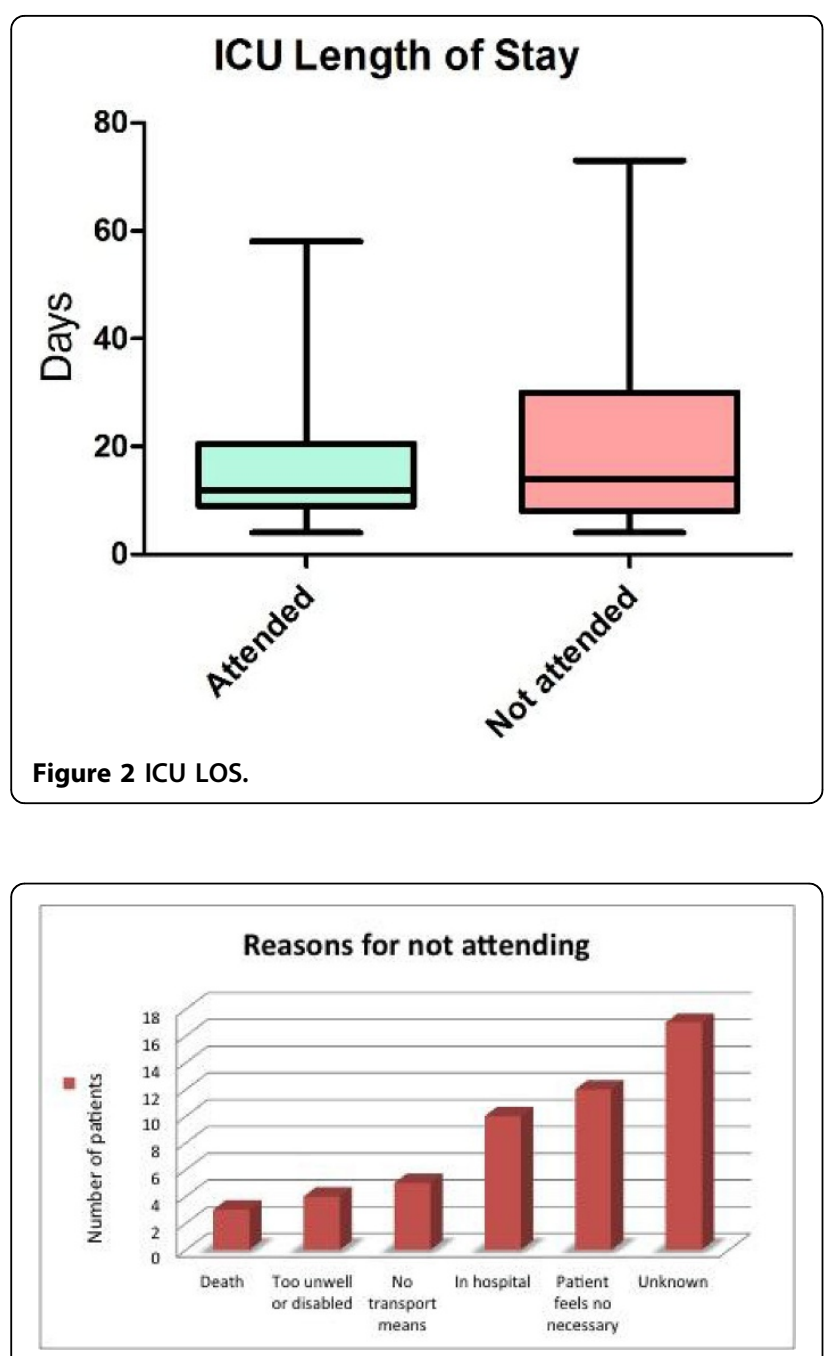

Figure 3 Reasons for not attending.

Published: 1 October 2015

\section{Reference}

1. NICE: Rehabilitation after critical illness NICE Clinical Guideline 83 London, UK: National Institute for Health and Clinical Excellence; 2009.

doi:10.1186/2197-425X-3-S1-A767

Cite this article as: Colomo et al:: Attendance rate in icu follow up clinics: an analysis of patients that attend the ICU clinic compared to those that do not attend. Intensive Care Medicine Experimental 2015 3(Suppl 1):A767.

\section{Submit your manuscript to a SpringerOpen ${ }^{\mathcal{O}}$ journal and benefit from:}

- Convenient online submission

- Rigorous peer review

- Immediate publication on acceptance

- Open access: articles freely available online

- High visibility within the field

- Retaining the copyright to your article

Submit your next manuscript at $\boldsymbol{s p r i n g e r o p e n . c o m ~}$ 